\title{
Traumland: um sonho desfeito
}

\author{
Traumland: a dream undone \\ http://dx.doi.org/10.11606/1982-8837203235
}

Laura Moosburger $^{1}$

\begin{abstract}
This paper aims to show the formative importance of the juvenile text Traumland to the poet Georg Trakl through an intense interpretative reading. This brief tale presents - as a recollection of the narrator - an experience of initiation or loss of innocence resulted from the perception of evil in the world, recognized in the sickness of his cousin Maria. The conflict between an enthusiastic and filled with expectancies romantic longing (Sehnsucht) and a terrifying reality which breaks the feeling of a cosmic harmony (Stimmung), drives a transformation in the ways the main character feels and views the world. This change can be metaphorically interpreted as a shift from a purely romantic poetic stance towards a standpoint keener to the XXth century's demands, especially in the sense of the acknowledgment of an unconquerable evil that cannot be fully romanticized.
\end{abstract}

Keywords:Sehnsucht; Romanticism;dream; Stimmung; compassion

Resumo: O intuito deste trabalho é destacar a importância do escrito juvenil Traumland para a formação do poeta Georg Trakl, por meio de uma leitura cerrada do texto. Sob a forma de uma lembrança do narrador, esse breve relato apresenta uma experiência de iniciação ou perda da inocência oriunda da percepção do mal no mundo, concentrado na figura de uma prima doente, Maria. O conflito entre o anseio romântico (Sehnsucht) pleno de expectativas e entusiasmo e essa realidade aterradora, vivenciado como uma quebra no sentimento (Stimmung) de harmonia cósmica, impulsiona uma transformação no sentimento e na visão de mundo do protagonista, que metaforicamente pode ser lida como a transição de uma poética puramente romântica para uma poética mais sintonizada com as exigências do século XX, especialmente no sentido da dimensão reconhecida ao mal irremediável, que não pode ser completamente romantizado.

Palavras-chave: Sehnsucht, romantismo, sonho, Stimmung, compaixão

"Aqui a minha alma de menino recebeu pela primeira vez as impressões de uma grande experiência." [Hier empfing meine Knabenseele zum erstenmale den Eindruck eines großen Erlebens.](TRAKL 2015: 1)

\section{Um romantismo em transformação}

Com um tom romântico acentuado e quase inesitante, a peça em prosa Traumland-eine Episode [Terra dos Sonhos - um episódio], ${ }^{2}$ de 1906, pode ser considerada uma exceção

\footnotetext{
${ }^{1}$ Universidade de São Paulo, Faculdade de Filosofia, Letras e Ciências Humanas, Departamento de Filosofia, Av. Prof. Luciano Gualberto, 315, São Paulo, SP, 05508-010, Brasil. E-mail: laurabmoos@gmail.com
} 


\section{Moosburger, L. Traumland}

na obra de Georg Trakl. É provável que, já sintonizado com as demandas do século e as vozes de vanguarda crescentes na produção da época, o autor tenha justamente por isso dado pouca importância em termos de acontecimento literário a esta que é uma de suas primeiras publicações, muito embora ela contenha um lirismo que pressagia sua poética madura: "Este ano trabalhei pouco, muito pouco! Só terminei pequenas narrativas. ${ }^{3} \mathrm{Meu}$ caminho parece tornar-se mais e mais difícil! Tanto melhor!"- eis a sucinta avaliação do poeta em carta a Karl von Kalmár (TRAKL1969: 471). Contudo, embora estimada de pouco valor literário por Trakl e, de modo geral, por seus estudiosos, buscaremos mostrar a fundamental importância de Terra dos Sonhos - um episódio no seu embate pessoal como poeta e na formação de sua visão de mundo, importância que não deixa de ser corroborada por sua exclamação de que as dificuldades lhe foram positivas.

Escrito sob a forma de uma rememoração intimista e confessional da "primeira grande experiência" do narrador, ainda que não de cunho diretamente autobiográfico, Traumland revela uma experiência transformadora no eu lírico trakliano. Levamos a sério em nossa leitura o fato de esse 'episódio' (conforme o título) ser relatado como uma reminiscência, remetida às primeiras impressões que atuaram sobre sua 'alma de menino', imbuídas portanto de um caráter iniciático e transformador. Exploramos a percepção de que esse breve escrito testemunha a profunda relação de Trakl com o romantismo e, simultaneamente, uma profunda transformação nessa relação.

A questão central que nos ocupa é a possibilidade da fé em uma transcendência, que marca a possibilidade de realização real ou virtual do infinito desejo (unendliche Sehnsucht) dos românticos. Pelo menos no primeiro romantismo, tal desejo encontrava uma contraparte metafísica - um Absoluto concebido como afim ao ser humano -, expressa no sentimento de harmonia cósmica (Stimmung). ASehnsuchté marcada por uma polaridade essencial: ora se direciona para o futuro plena de expectativas, esperança e entusiasmo, ora se volta para o passado, melancólica, ciente da distância que separa o homem do Absoluto.Katja LöHR propõe nesse sentido que a Sehnsucht seja entendida como Oberbegriff em relação à melancolia, pois abrange a esta como um de seus momentos (2003: 12). O verbete de KIRCHNER \& MichÄELIS assinala uma

\footnotetext{
${ }^{2}$ A tradução aqui utilizada, publicada pela Revista literária em tradução (n.t.) (ver Referências bibliográficas), é de nossa autoria. A revista (n.t.) disponibiliza suas edições em pdf pelo site <http://www.notadotradutor.com/>.

${ }^{3}$ Além de Traumland, o poeta se refere a Verlassenheit e às duas narrativas reunidas sob o título Aus goldenem Kelch:Barrabás - eine Phantasie, e Maria Magdalena - ein Dialog. Esses escritos também receberam tradução nossa e se encontram publicados pela revista (n.t.) (ver Referências bibliográficas).
} 
Moosburger, L. Traumland

dinâmica existencial: a Sehnsucht "perturba o homem em sua juventude como um anseio por algo desconhecido" e então, em idade mais avançada, "volta-se para trás com uma dor profunda pelos ideais perdidos" (1907: 559). Entretanto, no romantismo o horizonte de um Absoluto em algum nível sintonizado com o desejo humano perdura, mantendo acesa a fé na transcendência, o que em termos de movimento filosófico e literário indica uma potência: um laço com o Absoluto, a possibilidade de transcendência. ${ }^{4} \mathrm{~A}$ função do sonho é fundamental, na medida em que por ele o romântico não apenas pressente a realização do desejo infinito, como também conhece a almejada realidade transcendente - trata-se, em última instância, de um sonho compartilhado com o Universo -, como no caso de Novalis, para quem o sonho se tornou um imperativo. ${ }^{5}$ Assim, apesar de oscilar, o romantismo alemão teria se mantido, como sugere SPITZER, essencialmente dentro do sentimento de harmonia cósmica (1949: $233-4)^{6}$

Ao revelar um adolescente romântico na descoberta da vida, sensível ao extremo às impressões que vivencia, Traumland, como sintetiza ROLLESTON, "não esconde um apaixonado comprometimento com os ideais de inocência, imediatidade e intensidade que estavam no coração do primeiro romantismo" (1976: 77); por outro lado, o escrito elabora uma experiência de perda da inocência e da fé que irá abalar a confiança nessa entrega: o conflito entre um anseio romântico e a percepção inequívoca do mal no mundo, concentrado na figura de uma prima doente, Maria, abala a fé em uma possível transcendência e se torna incontornável para nosso autor, marcando o destino de sua voz poética madura. É digno de nota que, à exceção dos poemas juvenis Zigeuner e Crucifixus, este seja o único texto em que Trakl emprega a palavra Sehnsucht (quatro vezes,em um texto de três páginas)- em todo caso, o único no qual é assumida diretamente pelo eu lírico, enquanto sua obra posterior sobeja termos para melancolia (Melancholie, Schwermut), precisamente a tonalidade da Sehnsucht que se vê destituída

\footnotetext{
${ }^{4} \mathrm{O}$ anseio de futuro como algo inesgotável foi paradigmaticamente elaborado por Fichte em sua Verificação sobre as afirmações de Rousseau, e o projeto do primeiro romantismo tal como formulado por Schlegel e Novalis insiste na infinitude e inesgotabilidade da Sehnsucht no sentido da infinitude não só do desejo, mas também de suas possibilidades de realização, ou seja, da perpetuidade de uma dinâmica que tem o futuro como horizonte perene. Essa concepção pressupõe um laço indelével entre o homem finito e o Absoluto.

${ }^{5}$ A esse respeito, ver BÉGUIN, 1954: 242-70.

${ }^{6}$ A leitura sobre o romantismo brevemente sintetizada neste parágrafo e a análise de sua relação com a poesia de Trakl, feita sob o fio condutor do entrelaçamento entre esse par de palavras-chave - Sehnsucht e Stimmung - é por nós trabalhada de forma mais ampla em pesquisa de doutorado, de que o presente artigo é um resultado parcial. Aqui buscamos apenas sintetizar as linhas gerais dessas relações de modo suficiente para podermos nos deter na dinâmica do anseio romântico e do sentimento de harmonia cósmica especificamente em Terra dos Sonhos.
} 
Moosburger, L. Traumland

de entusiasmo e esperanças de realização. A ocorrência textual do termo Sehnsucht, é claro, não necessariamente coincide com sua presença enquanto afeto; mas a disposição do poeta por admiti-lo ou não textualmente é um forte indicador de seu posicionamento perante o afeto: que tonalidade do afeto pode ainda ser admitida? Pode a Sehnsucht, em sua aspiração, continuar nutrindo esperanças de realização, ou só pode expressar-se como melancolia por algo que se tornou impossível?

Certamente não devemos esquecer que mesmo no romantismo a Sehnsucht frequentemente é melancolia e "os ideais de inocência, imediatidade e intensidade" eram, justamente, ideais de um homem ciente de sua experiência de separação e perda, mote repetidamente proferido pelos românticos. Todavia, no romantismo, mesmo quando a Sehnsucht não alcança o Absoluto, ela ao menos tende a permanecer oscilante entre os polos otimista e pessimista, podendo retornar da melancolia ao entusiasmo e à esperança, por exemplo. No desenvolvimento da obra trakliana, a experiência de cisão é a tal ponto radicalizada e a melancolia se torna a tal ponto preponderante, que a Sehnsucht já não retorna a outras tonalidades, sinalizando uma perda irrecuperável inclusive da possibilidade de ter um ideal. O que buscamos ressaltar é precisamente a ocorrência de uma quebra no sentimento de harmonia cósmica, em que o sonho perde sua capacidade de unir o homem ao Absoluto e passa a representar a cisão com uma realidade desprovida de transcendência. Para tanto, exploraremos em Traumland a presença complexa da Sehnsucht, como esperança idealizadora, expectativa e entusiasmo ante o futuro, como plenitude presente do desejo, mas também em seu tornar-se melancolia a partir da falta e da perda, marcadas na quebra do sentimento de harmonia. Com isso, abrimos caminho para melhor dimensionar os conflitos entre uma poética puramente romântica e uma mais atenta às demandas do tempo em que esse poeta viveu. ${ }^{7}$

LINDENBERGER (1954: 45) já notara que quase toda discussão da poesia trakliana praticamente ignorou sua obra inicial, e este é também o caso de Traumland. Poucos são os estudiosos que se debruçaram sobre esse escrito juvenil, o que em grande parte se deve ao juízo de seu valor literário menor. Regine BLASS (1968), embora seja uma exceção por iniciar seu estudo Die Dichtung Georg Trakls: von der Trivialsprache zum

\footnotetext{
${ }^{7} \mathrm{O}$ artigo não detalha traços conceptivos e estilísticos das vanguardas no texto analisado; a proposta é mostrar que a dimensão do mal irremediável impulsiona uma transformação na Stimmung do eu lírico e na função do sonho, ocasionando a perda da transcendência e do idílio, no que se pode ver a elaboração de muitas das bases existenciais - ou de uma "nova consciência existencial", na expressão de KASACK (1968: 362) - de movimentos do séc. XX.
} 


\section{Moosburger, L. Traumland}

Kunstwerk com uma detida análise desse escrito, baseia sua escolha, contudo, no fato de considerá-lo exemplar da linguagem menos poética e refinada das primeiras produções do autor. Sua proposta é analisar o progresso da poesia trakliana sob o ponto de vista da passagem da linguagem trivial à obra de arte; porém, essa perspectiva, por mais pertinente e elucidativa que seja, terminou onerando sua interpretação do texto com um criticismo que passa ao largo de questões fundadoras da obra de Trakl e que merecem ser exploradas. BLASS fornece como razão de seu juízo de que Traumland apresenta uma "qualidade estética muito limitada" o fato de seu conteúdo descritivo ser muito sucinto e vago: sente falta de informações sobre a cidade em que se desenrola a estória, sobre as pessoas e suas atividades, bem como de uma "descrição conceitual refinada" (1968: 11). O primeiro pressuposto dessa crítica é que estamos diante de um texto em prosa. Sabemos, porém, que Trakl cedo optou pela poesia, e mesmo seus textos futuros em prosa são em prosa poética. Isso precisa ser levado em conta, e Traumland pede ser lido em seu lirismo. Mas Blass também desaprova a poeticidade do texto: nele "não é cunhada nenhuma linguagem poética, não há metáforas felizes", sua linguagem é "trivial” (BLASS1968: 11). Tais críticas serão retomadas e questionadas no horizonte de leitura aqui proposto, que visa a um objetivo bastante diferente: não comprovar a qualidade performática do texto, mas mostrar sua relevância na formação espiritual do poeta, destacando dentro disso a sua qualidade expressiva própria.

\section{Um sonho que se desfaz}

O texto abre com o narrador adulto rememorando em tom de saudosa ternura o período mais feliz de sua vida: "Por vezes me vejo pensando novamente naqueles dias silenciosos, que são para mim como uma vida fantástica e maravilhosamente vivida, que eu podia desfrutar sem hesitação como um presente recebido de mãos benevolentes e desconhecidas." (TRAKL 2015: 103). Essa época de ouro - oito semanas de férias de verão passadas na casa de seu tio em uma pequena cidade - refere-se claramente a uma infância, no sentido mesmo em que o narrador a descreve: uma dádiva, aceita e fruída com inocência, tranquilidade, com uma alegria pura, livre de preocupação ou receio. A vida mesma era um presente (nos dois sentidos da palavra) do qual podia desfrutar como de um sonho bom. Logo fica claro que o objeto da nostalgia não é apenas a 
infância, pois a simples recordação daquele tempo faz afluir-lhe à lembrança todo um cenário de plenitude:

[...] E aquela pequena cidade ao fundo do vale surge novamente em minha memória com sua larga rua principal, por onde se estende uma longa alameda de esplêndidas tílias; com suas ruelas angulosas, plenas de uma vida secretamente laboriosa de pequenos comerciantes e artesãos - e com a antiga fonte da cidade no meio da praça, respingando ao sol como em um sonho, e onde à noitinha sussurros de amor se misturam ao murmúrio da água. Mas a cidade parece sonhar com uma vida passada (TRAKL2015: 103).

A harmonia da infância, que remete ao registro do tempo, foi vivida no idílio de um lugar - uma pequena cidade como acolhida ao fundo do vale -, o que já traz a ideia de que a totalidade espaço-temporal da existência foi vivida como uma totalidade harmônica. ${ }^{8}$ A descrição segue um crescendo: começa pela longa alameda de esplêndidas tílias, passa pela vida secretamente laboriosa dos pequenos artesãos, para culminar na "antiga fonte da cidade no meio da praça, respingando ao sol como em um sonho". Enquanto a imagem da alameda de tílias sugere integração entre cidade e natureza, bem como amplitude ("longa alameda", "larga rua principal"), a vida singela dos artesãos adverte uma plenitude humana preenchendo as bifurcações da cidade, e a imagem da fonte no meio da praça, no centro da cidade, reúne em si todos esses elementos - o que se percebe a uma vez pela cadência do texto e pela localização central da fonte, mas também porque fontes/chafarizes representam harmonia entre natureza e civilização. A visão da corrente d'água encontrando o sol sugere culminância e a força agregadora da corrente ${ }^{9}$ dá a sensação de que toda a vida até ali descrita é por ela como levada a encontrar-se com o brilho do sol. Associada à fonte está ainda a imagem do amor, cujos sussurros "se misturam ao murmúrio da água" - Trakl joga com a consonância onomatopeica das palavras, evidenciando a harmonia sonora dos elementos: “[...] der im Sonnenschein so verträumt plätschert, und wo am Abend zum Rauschen des Wassers Liebes geflüster klingt" (TRAKL 2015: 99, grifo nosso). Não apenas a união amorosa, no imaginário romântico, é um ápice da fusão na totalidade ansiada pelo homem, como aqui ela ainda se confunde ao rumorejo da fonte, intensificando-se a imagem de harmonia romântica, "como em um sonho".

\footnotetext{
${ }^{8}$ Esse sentido de totalidade é explanado por MALPAS (2010: 88) em vista do sentido existencial da nostalgia como anseio de volta ao lar: um lar não é só espacial ou só temporal, mas "um lugar que sustém em si espaço e tempo".

9 Além do sentido de pureza, relevante no contexto, um dos aspectos da simbologia da água a ser destacado é o de ser, além de fonte, também condutora da vida; ver, p. ex., CHEVALIER\&GHEERBRANT 1989: $15-6$.
} 
Não deve passar despercebida a escolha do autor por exprimir a dimensão onírica com o termo verträumt - “... dem alten Stadtbrunnen..., der im Sonnenschein so verträumt plätschert” (TRAKL 2015: 99, grifo nosso), “... a fonte [...] respingando ao sol como em um sonho" -; em sentido literal, o termo indica o estado anímico do sonhador, mas também pode descrever um cenário ou objeto capaz de induzir ao sonho, bem como uma cena produzida por um sujeito nesse estado. Trakl logrou com isso um efeito ambíguo, mantendo todos esses sentidos: tanto pode a fonte estar sonhando encantada, quanto pode com seu ar onírico provocar o sonho no observador, ou esse ar onírico pode ser uma projeção no objeto da atividade sonhadora do observador. O próprio objeto pode ser tal projeção; nesse caso, a fonte é apenas um sonho. Mas sujeito do sonho não é apenas a fonte, e sim toda a cidade: "A cidade parece sonhar ${ }^{10}$ com uma vida passada..."; o cenário, o lugar como um todo sonhava. Ao mesmo tempo, como corrobora a amplitude semântica de verträumt, ${ }^{11}$ o menino era sonhador e tudo se lhe afigurava onírico. As duas coisas se confundem, revelando que o menino encontrava na cidade uma ressonância de sua própria subjetividade, o que marca a coerência de sua Stimmung, na medida em que dessa forma toma parte num sonho universal. Assim, a saudade se refere à sua infância porque aí ele conheceu a unidade romântica com a vida e o mundo: um lugar-tempo em que não apenas não havia divórcio entre ele e sua vida, como tampouco entre sua vida e o mundo, e o mundo, por sua vez, era coeso em suas várias instâncias (cidade, natureza...). Esse lugar-tempo tem a dimensão existencial e ontológica de um sonho de unidade e harmonia, uma terra de sonhos que agora lhe surge perdida.

Que se trata de uma perda e de uma nostalgia profunda daí resultante, já se percebe pela forma como o narrador abre o parágrafo, dizendo ser compelido a tais lembranças - "Manchmal muß ich wieder jener stillen Tage gedenken...” (TRAKL 2015: 99, grifo nosso) -, incapaz de deixá-las ir. A dinâmica da nostalgia revela sua força ao percebermos no texto uma duplicidade ao mesmo tempo que uma interpenetração entre

\footnotetext{
${ }^{10}$ Cabe observar que o "parece" não se refere diretamente ao ato de sonhar, mas ao fato de o sonho ser de uma vida passada. Com isso não foi retirado o peso da afirmação de que a cidade sonha, antes retirou-se a realidade do sonho como um todo. Falaremos disso na sequência.

${ }^{11}$ Essa estrutura aparece em outra passagem (grifos nossos): “[...] inmitten all' der leuchtenden Blumen, über die verträumt große gelbe Schmetterlinge schwebten [...]”, “[...] em meio a todas aquelas flores luminosas sobre as quais grandes borboletas amarelas pairavam oniricamente [...]" (TRAKL 2015: 102; 105-6 ); em Verlassenheit, do mesmo ano, aparece a seguinte construção: "Die Wasserlilien winken ihm $\mathrm{zu}$, wie kleine, tote Frauenhände, und wiegen sich nach den leisen Tönen des Windes, traurig träumerisch", "Os lírios d'água acenam para ele, como pequenas, mortas mãos de mulher, e balançam aos sons suaves do vento, como em um triste sonho" (TRAKL 2016: 161; 171).
} 
o ato de lembrar e aquilo que é lembrado: ao iniciar sua descrição pela larga rua principal o narrador como que realiza uma viagem pelo longo e largo túnel da memória, no qual já aparece ao viajante a sucessão de tílias e pelo qual ele vai adentrando novamente o lugar de sua infância perdida, suscitando a amplitude da vida toda que ele tinha pela frente, perfilando imagens de beleza e plenitude; nesse caso, a imagem da fonte que coroa a sequência é simultaneamente o centro da cidade e da sua lembrança. Aquilo de que ele se recorda e o ato memorativo misturam-se de tal forma que, potencializando-se ainda mais o efeito nostálgico, é dito após o ápice da imagem da fonte, fechando o parágrafo: "Mas a cidade parece sonhar com uma vida passada". Mesmo o que revive em sua memória está a sonhar com uma vida passada, como se jamais houvesse sido presente. Mais, o sujeito do sonho é a uma vez o narrador e a cidade: o narrador nesse instante identifica-se completamente com o passado perdido. Lido como um poema, em seu fluxo musical, o parágrafo começa num crescendo, atinge um pico e termina numa languidez, dissipando-se numa desrealização em que passado e presente, cidade e sujeito se diluem juntos. Isso dará o tom de todo o escrito, que se move na tensão entre a plenitude harmônica da terra dos sonhos e a perda constante que a acompanha como memória, ${ }^{12}$ conferindo à sua dinâmica temporal uma condensação extrema: a ocorrência simultânea de recuperação e perda, inclusive pela intercalação dos tempos verbais no passado que amiúde é descrito como presente. Enquanto as lembranças afluem com vivacidade e nitidez, o tom de memória perdura, ainda que momentânea ou aparentemente suspenso, misturando presente e passado; por sua vez, o futuro é inserido na narrativa desde o início, seja como projeção desde o passado, seja como atribuição retroativa de sentido pelo narrador em seu presente.

A dinâmica temporal condensativa revela-se na ocorrência simultânea de passado e presente como duas fases da vida, infância e vida adulta, condensadas na transição da adolescência (o protagonista se descreve como um Schulbube, colegial, portanto um jovem na aurora da adolescência). Isso coloca uma questão sobre o objeto

12 MALPAS observa que a nostalgia, ao presentificar o passado perdido, comporta não apenas a dor da perda, mas também um sentimento de familiaridade e conforto, pela reexperimentação de "sons, cheiros, visões familiares que evocam a presença do lar mesmo em sua ausência. Tais experiências, nas quais o lar ansiado reaparece, brevemente talvez, mas amiúde com clareza impressionante, alcançam uma certa forma de retorno ao lar em que a dor da nostalgia pode ser temporariamente aliviada, muito embora possa, como consequência, ser também exacerbada" (2010: 88-9). Trata-se de uma tensão inerente ao afeto: "A memória do passado, na medida em que é memória, tem de permanecer sempre em contraste com o presente, e assim, mesmo quando experienciada como prazerosa e reconfortante, permanece uma experiência tingida com um sentido de perda e estranhamento. O estado de espírito da nostalgia [...] permanece assim sempre em algum lugar entre nostos e algos - entre o retorno à casa e a dor de sua perda irrevogável” (2010: 89). 
Moosburger, L. Traumland

de sua nostalgia no tocante à dimensão temporal. Há a clara marcação de um antes e depois, no terceiro parágrafo: “Oito semanas vivi nesse afastamento, e essas oito semanas são para mim como uma parte separada e autônoma da minha vida - uma vida por si - cheia de uma felicidade indescritível, juvenil, cheia de um intenso desejo (starke Sehnsucht) por coisas belas e distantes" (TRAKL 2015: 103). O destaque da separação já é dado no registro espacial do afastamento (Entlegenheit), pois a cidade ficava ao fundo do vale, recolhida e retirada porque "silenciosas e solenes florestas de abetos isolavam o vale do mundo exterior"; então, no registro temporal, o destaque é investido de um sentido quase material pelas palavras "losgelöster, eigener Teil" (parte separada/avulsa e autônoma). O destaque decerto se refere ao antes e depois de infância e maturidade, mas o momento rememorado é o da idade juvenil entre a criança e o adulto, que a ambos condensa na experiência de transição. Isso é enfatizado na conclusão do parágrafo: “Aqui a minha alma de menino recebeu pela primeira vez as impressões de uma grande experiência” (TRAKL 2015: 103).O subtítulo 'um episódio' indica nesse sentido a primeira grande experiência, que para ser gestada e adolescida requer um período de afastamento. As saudades revelam que nessa experiência algo foi perdido, justamente essa "vida por si - cheia de uma felicidade indescritível, juvenil, cheia de um intenso desejo por coisas belas e distantes", refletindo a já mencionada dinâmica temporal da Sehnsucht: seu direcionar-se para o futuro como expectativa, esperança, entusiasmo e, para o passado, como desesperança e nostálgica melancolia. A aparente obviedade do tema (a perda do paraíso infantil) não deve induzir-nos a deixar de explorar o que o protagonista perdeu com a perda da infância, o que nomeou de terra dos sonhos; o que enfim foi sua primeira grande experiência. A fim de explicitar o entrelaçamento e ruptura entre essas fases, infância, adolescência, vida adulta, tal como se realiza no processo de perda, prosseguimos com uma análise em dois tempos, lendo em separado etapas que, condensadas em uma experiência única, ocorrem simultaneamente. No primeiro tempo, exploramos a Stimmung de unidade harmônica que o narrador de início caracterizou como "um presente recebido de mãos benevolentes e desconhecidas"; no segundo, a quebra nessa Stimmung, os elementos dissonantes que concorrem para a experiência de perda, correlacionando esses dois tempos em sua tensão interna para a constituição futura do espírito do protagonista.

À medida que o texto avança, a atmosfera de unidade e completude harmônica vai-se mostrando em vários níveis. Já notamos que "a pequena cidade ao fundo do vale" 
sugere acolhimento da cidade pela natureza. Isso fica mais evidente no terceiro parágrafo:

E colinas levemente curvadas, cobertas por silenciosas e solenes florestas de abetos, isolam o vale do mundo exterior. Os cimos repousam suavemente contra o céu distante e luminoso, e nesse contato de céu e terra o torrão natal parece abrigar todo o universo (TRAKL2015: 103).

O denso arvoredo em sua solenidade e silêncio resguarda a terra dos sonhos, como velando-a, o que suscita o motivo da 'mãe terra' acolhedora. Não apenas da terra: o acolhimento é do universo como um todo, a terra dos sonhos situa-se precisamente no encontro de céu e terra, motivo romântico da unidade e totalidade. A sugestão de acolhimento se reforça na imagem dos cimos que "repousam suavemente", como num ninho em que a intimidade (torrão natal) encontra a imensidão (todo o universo). Notese a inversão: não o torrão natal é uma parte do universo, mas o universo uma parte do torrão natal: "in dieser Berührung von Himmel und Erde scheint einem der Weltraum ein Teil der Heimat zu sein" (TRAKL 2015: 99, grifo nosso). Assim, o isolamento não significa apartação, mas preservação da totalidade. Preservação também em relação a algo externo, que ao fim da narrativa é nomeado: "a cidade grande". A "pequena cidade" e "a cidade grande" podem ser metáforas respectivamente da infância e da vida adulta. Há então dois mundos externos no texto: aquele do qual a terra dos sonhos está isolada e que seria alheio ao paraíso da infância (e que ao fim da narrativa é sumariamente nomeado "a cidade grande"), e aquele que ela mesma é enquanto localidade da infância: entorno, portanto, que preserva o paraíso da infância. A este mundo externo o sujeito se sente intimamente unido.

Uma análise detida pode mostrar que a unidade perpassa os planos natural, humano e cósmico. Cada elemento da natureza é harmônico em si, e estão em harmonia uns com os outros. A água rumoreja, o sol brilha, o céu cintila, as flores são luminosas e perfumadas. Juntos, compõem um cenário idílico. Idílio não é apenas o belo cenário, mas a união compositiva dos elementos que permite ao cenário ser harmonioso; a começar pela integração das colinas curvadas com a floresta de abetos e os cimos que repousam contra o céu - configuração natural que garante a possibilidade ontológica da terra dos sonhos -, o texto é repleto de imagens de junção de elementos naturais: o "vento morno" "era pleno do aroma forte e inebriante das rosas"(TRAKL 2015: 104), no jardim o menino percebia "as cores vibrantes das inflorescências inundadas pela luz do sol", "a quietude do ar, só ocasionalmente interrompida pelo chamado de um 
Moosburger, L. Traumland

pássaro"(TRAKL 2015: 105). O vento carrega o perfume das flores, que vibram coloridas pela luz solar, e mesmo o chamado do pássaro que interrompe a quietude o faz com harmonia. E esses elementos/eventos naturais se integram, compondo juntos o cenário idílico, já incorporado à civilização: a cidade é acolhida ao fundo do vale, a alameda de tílias se estende pela rua principal, os artesãos preenchem com sua vida laboriosa as bifurcações da cidade, a fonte no meio da praça congrega o esforço humano e a fonte natural de vida. $\mathrm{O}$ vento morno do anoitecer (natureza) soprava pela janela (entrada para a habitação construída pelo homem), e era pleno do aroma das rosas (natureza) que floresciam junto à cerca (constructo humano) do jardim (que, tal como a fonte, congrega natureza e artifício humano). A "poeirenta rua principal (cidade) emanava o perfume das tílias em flor (natureza)" (TRAKL 2015: 104). A palavra Traumland é perfeita nesse sentido, visto que Land, traduzível tanto por 'terra' quanto por 'cidade' ou 'país', reúne natureza e civilização. No plano humano, há a harmonia das pessoas, que "podiam confiar sem medo umas às outras todos os seus pequenos sofrimentos e alegrias", e que o narrador encontra sobretudo em seu círculo mais próximo, junto ao tio e à prima: “Talvez essas horas em que nós dois [ele e Maria] sentávamos juntos e fruíamos calados uma grande, quieta e profunda felicidade fossem tão bonitas, que eu não precisava desejar nada mais belo. Meu velho tio consentia com esse nosso silêncio" (TRAKL 2015: 105). Ápice da harmonia humana é porém a imagem do casal vislumbrada junto à fonte; introduzida na abertura do texto, essa imagem será retomada mais tarde em uma versão mais forte: “[...] quando via duas pessoas estreitamente aconchegadas uma à outra e embaladas pelo suave rumorejo da fonte lentamente fundirem-se ao luar como se fossem um só ser [...]"(TrAKL 2015: 104). A unidade se desdobra como integração da natureza consigo mesma, da natureza com a cidade, da cidade com os homens, dos homens entre si e, finalmente, culmina na imagem do casal tornando-se um só ser ao luar, como se tudo o mais se reunisse através de sua união. Sob o pano de fundo da noite enluarada, as coisas estão todas em harmonia, afinadas (gestimmt).

Em todos os níveis da harmonia está a percepção do eu. Apuramos no primeiro parágrafo uma fusão do eu com aquilo de que ele se lembra, a descrição do que é rememorado refletindo o movimento de seu nostálgico retorno. Isso também ocorre no modo como o narrador nos conduz a seu mundo interior: dando sequência ao gesto da natureza que abriga a cidade ao fundo do vale e do torrão natal que contém o universo, ele nos aproxima da "pequena casa com seu pequeno jardim à frente", que, "um tanto afastada da cidade", "ficava quase completamente encoberta por árvores e arbustos", na 
qual "habitava um pequeno sótão, decorado com maravilhosos quadros antigos e desbotados, onde tantas tardes passei sonhando no silêncio meus devaneios aéreos, tolamente felizes de menino [...]" (TRAKL 2015: 104). Começando por situar espacialmente a pequena cidade (resguardada ao fundo do vale pela espessura das florestas de abeto), depois a pequena casa (afastada da cidade e encoberta por árvores e arbustos), então o pequeno sótão (parte mais recolhida da casa) - topografia que, nas palavras de Gunther KLEEFELD, "segue a representação de um ser-envolvido" (1985: 277) - o escritor obtém o efeito de camadas ou cortinas que vão sendo removidas, conduzindo-nos finalmente ao ninho que abriga os sonhos desse menino, como se o mundo externo fosse gradativamente se transformando em seu mundo interno. O lugar é apresentado como uma imagem do estado espiritual do protagonista: recolhido como a cidade, repousando suavemente como os cimos, pode gestar sua primeira grande experiência; realizando o mesmo movimento do menino que se recolhe, o ambiente era propício à alma, como uma espécie de conspiração entre universo e alma.

A interpenetração e espelhamento de mundo externo e interno exprime-se de forma análoga à interpenetração e espelhamento entre lembrança e lembrado que constatamos no primeiro parágrafo e que aqui ressurge na imagem dos quadros ${ }^{13}$ "antigos e desbotados" que decoram o quarto: eles poderiam encontrar-se em tal estado pelo efeito da memória do narrador, entretanto já assim estavam no passado. A dinâmica da memória nostálgica e a atmosfera onírica associam-se assim no processo de fusão do sujeito com o mundo. Com relação especificamente ao sonho, porém, é preciso fazer uma distinção entre dois níveis nesse processo de fusão: se o sonho, assim como a memória, é constitutivo da subjetividade simplesmente considerada como existência, ou seja, se o caráter de sonho enquanto tal é constitutivo de uma experiência de mundo, como uma condição existencial permanente, há no texto, além disso,a unidade onírica do sujeito com o mundo no sentido específico de idílio e dacorrespondência de propósitos, o que já implica uma concordância entre expectativas subjetivas e um desígnio mais amplo. Em outros termos: o sonho particular do sujeito é sentido como algo compartilhado com o universo. Tal distinção é fundamental porque - como pontuamos na introdução e retomaremos nas considerações finais deste artigo - essa segunda forma de fusão do sujeito com o mundo através do sonho (a de uma

${ }^{13} \mathrm{O}$ termo usado em alemão, Bild, pode neste contexto significar pinturas, gravuras ou fotografias, mas mais provavelmente fotografias ou algum tipo de imagem impressa, pois pinturas ao envelhecer via de regra escurecem, não desbotam. À falta de uma confirmação, optamos pelo equivalente neutro em português. 
correspondência ou sintonia de propósitos) é precisamente a marca do romantismo que se torna problemática para Trakl.

Como buscamos assinalar, isso que chamamos de correspondência de propósitos insinua-se no texto em diversos momentos. O próprio estado de sonho do narrador está associado ao sentimento de ser acolhido: “[...] devaneios que o silêncio amorosamente acolhia e resguardava em si, para por vezes trazê-los de volta a mim mais tarde - nas horas solitárias do crepúsculo". A forma de expressão indica, mais que uma afinação, uma afinidade essencial entre o sujeito e a vida. $O$ silêncio, que não é apenas do jovem, mas da vida, do entorno, enfim, de uma esfera ontológica que transcende o sujeito, acolhia amorosamente os seus devaneios silenciosos, os resguardava em si, e os trazia de volta mais tarde, nas horas propícias do entardecer. E se as horas crepusculares o enlevavam em sonhos, a noite surge como uma espécie de coroamento disso: "Lentamente a noite penetrava o cômodo, e então eu levantava, dizia 'boa noite' e subia novamente para o meu quarto no sótão, para sonhar à janela por mais uma hora noite adentro" (TRAKL 2015: 104); “então eu voltava a refugiar-me em meu sótão, reclinava-me à janela, contemplava o profundo céu escuro, no qual as estrelas pareciam se extinguir, e por horas me entregava a turvos sonhos entorpecentes, até que o sono me dominasse" (TRAKL 2015: 105). Nas duas passagens podemos notar um aprofundamento na intimidade, que é simultaneamente a intimidade de uma esfera ontológica mais ampla: ele se recolhe no sótão como quem retorna a um abrigo, e então sonha noite adentro - a expressão "in die Nacht hinaus zu träumen", literalmente "para sonhar noite afora/ na noite lá fora”, foca na amplidão noturna, mas nela o sonhador mergulha, como se a substância de seu sonho se fundisse à noite -; ou então mirava o profundo céu escuro, nos quais as estrelas pareciam se extinguir (como em um profundo infinito), e por horas (stundenlang, um tempo indefinidamente longo) entregava-se a "turvos sonhos entorpecentes", como fundindo sua subjetividade semiadormecida ao infinito da noite, até ser dominado pelo infinito do sono - sem perder o sentido de acolhimento, pois a descrição remete a um adormecer embalado pelos sonhos e pela noite, como quem se reconforta. O sentimento do infinito encontra na noite e no sono um leito que embala, em uma espécie de conspiração entre o universo e o íntimo.

Entretanto, em termos de intensidade, o jovem sonhador encontra ápices de unidade e consonância também nos momentos mais focados na realidade sensível e imediata, quando está voltado para o mundo externo na plenitude de seus sentidos. Em 


\section{Moosburger, L. Traumland}

passeios pelo bosque durante o dia sentia-se "tão alegre na solidão e quietude" e quando cansado se "esticava sobre o musgo e por horas mirava o céu claro e cintilante, em cujas distâncias se podia olhar tão profundamente", um "sentimento estranho e profundo de bem-aventurança me arrebatava" (TRAKL 2015: 104). Nessa imagem o menino parece fazer a ponte entre céu e terra: o corpo pesando sobre a terra, acolchoado no musgo, a alma mirando a distância azul, o sentimento "estranho e profundo de bem-aventurança" bem pode ser um sentir vago, porém intenso, da reunião que ele realiza entre céu e terra, que por sua vez se confunde àquele pressentimento de coisas belas e distantes, aqui vislumbrado na profunda amplitude do céu. Ele se deixa absorver pela promessa de um futuro ansiado, sentido na terra que acolhe o corpo e pressentido no céu em que a alma sonhadora se expande - um ápice de sua infinita Sehnsucht. Nas tardes passadas no jardim, "deitava na grama e aspirava o perfume de mil flores", seus olhos "se embriagavam com as cores vibrantes das inflorescências inundadas pela luz do sol”, e ele "ouvia a quietude do ar, só ocasionalmente interrompida pelo chamado de um pássaro", e "sentia o fermentar da terra úmida e fecunda, esse som misterioso da vida eternamente criadora" (TRAKL 2015: 105). Também aqui mediando terra e céu, o jovem agora sente/pressente o fundo e a fonte unitária da vida, a terra eternamente criadora da exuberância multiforme e multicor do mundo externo, o qual revela simultaneamente uma dimensão espiritual - na luz que inundava as inflorescências e na amplitude do céu, cruzada pelo chamado de um pássaro. ${ }^{14}$ A terra é sentida como a eterna geradora do paraíso sensitivo que o protagonista, na flor da juventude, recolhe com sua sensibilidade aguçada e porosa. A palavra Traumland nesse sentido não significa apenas a reunião de natureza e civilização, mas, para além disso, a misteriosa reunião da natureza, imanência geradora, com um mundo espiritual que a transcende. Mistério que o jovem conectado a essas duas dimensões e seguro de sua unidade sente em seu íntimo: "Nesses momentos eu percebia obscuramente a grandeza e beleza da vida. Nesses momentos eu também sentia como se a vida me pertencesse" (TRAKL 2015: 105), diz ele, revelando novamente um ápice de sua Sehnsucht, que cabe analisar em detalhe.

$\mathrm{Na}$ intimidade de seus sentidos suscetíveis ele percebia a íntima unidade da natureza, seus sentidos palpitavam em consonância com ela. $\mathrm{Na}$ imediatez das sensações as coisas lhe surgem ao modo de uma harmonia, uma harmonia que não se

\footnotetext{
${ }^{14} \mathrm{O}$ céu e a luz que dele emana, enquanto indicadores de uma dimensão espiritual e manifestações da transcendência (cf. p. ex. CHEVALIER \& GHEERBRANT 1989: 227; 567-71), foram amplamente usados no romantismo.
} 


\section{Moosburger, L. Traumland}

limita ao que ele contempla no mundo externo através dos sentidos, mas abrange uma sincronicidade entre o que é revelado externamente e o que é sentido internamente. $\mathrm{Na}$ imagem das inflorescências inundadas pela luz do sol sugere-se que a visão do menino é inundada pela visão das flores e pela luz do sol que inunda simultaneamente as flores e sua visão; na imagem das "rosas pejadas de perfume", sugere-se também um olfato pejado de perfume; quando o pássaro interrompe com seu chamado a quietude do ar, insinua-se que ele chama a alma silenciosa do menino, cuja amplitude e profundidade, através dos sentidos, confundem-se ao ar e ao céu. Tudo isso é sugerido no texto, e o fato de as descrições serem sucintas - ao contrário de uma falha, como entende Blass -, se entendido como condensação, aponta para a intensidade poética de cada sensação, de cada elemento descrito, e para o fato de que nessa sensibilidade poética o protagonista se sente intimamente vinculado ao todo. Se mais que isso fosse dito, talvez se perdesse justamente o sentido de fusão e imediatez que constituem sua experiência íntima mais própria.

Enfim, se a unidade de todas as coisas é vislumbrada exteriormente, é a integração do jovem com sua ambiência que lhe permite perceber a integração externa. O que "mantém tudo reunido" é uma Stimmung que não é só o seu estado de espírito, mas o caráter de um sonho bom compartilhado com o universo: essa Stimmung ganha o tom de uma conspiração, uma cumplicidade do menino com a Terra, com o céu, com as sensações. Na passagem em que ele sente o "fermentar da terra eternamente criadora" e "sente obscuramente a beleza e grandeza da vida", "como se a vida me pertencesse", pode-se sentir um tom teleológico, de que a vida, o mundo foi feito para esse jovem coração que pulsa e amorosamente recolhe as sensações do mundo que o cerca sentimento que no romantismo investe, por exemplo, os motivos novalisianos da flor azul e da noite de um sentido de presságio de realização da infinita Sehnsucht.

BLASS observa que a realidade é percebida pelo narrador como temporal e espacialmente ilimitada. Passagens como aquela em que, contemplando o céu noturno de sua janela, ele se entrega a sonhos até adormecer, e quando à tarde no bosque mira a distância celeste, dão notícia de uma ultrapassagem da dimensão transitória do tempo para um tempo sentido como ilimitado e eterno (1968: 30). Da mesma forma, a descrição do ambiente indica uma amplitude, como na passagem inicial das colinas que isolam o vale e, na cena do jardim, a percepção de "mil flores", "inundadas pela luz do sol". A autora defende, porém, que a grandeza do mundo externo serve "apenas como 
Moosburger, L. Traumland

meio para exprimir o sentimento de ilimitação (das grezenlose Gefühl) do narrador" (1968: 31). Mas é fundamental notar que para esse eu não se trata de uma projeção, ele tem o sentimento seguro (“[...] um presente que eu podia receber sem hesitação [...]”) de ser acolhido pela cidade, pela natureza, pelo fluxo do tempo que parece aproximar-se e suspender-se na eternidade. Tal acolhimento também se exprime no seu círculo humano, compartilhado como tio e a prima: “Talvez essas horas em que nós dois sentávamos juntos e fruíamos calados uma grande, quieta e profunda felicidade fossem tão bonitas, que eu não precisava desejar nada mais belo. Meu velho tio consentia com esse nosso silêncio" (TRAKL 2015:105). O silêncio do tio, tal como o silêncio que acolhia seus devaneios,tem a função de uma dimensão mais ampla que consente com seus anseios, e justamente por se tratar de uma figura humana evidencia a transferência "antropomórfica" das expectativas e pressentimentos do jovem a essa dimensão maior, fazendo-o vivenciar seu sentimento de infinito como uma consonância com o universo.

Essa passagem corrobora a impressão de que a brevidade do relato se deve ao seu teor poético, e além disso à singeleza das vivências do jovem, ou melhor, o poético dessas vivências reside justamente em sua singeleza. O que ele diz dos momentos de silêncio compartilhados com a prima pode valer para todas as demais situações descritas com afetuosidade, singelas e por si só intensas. Assim como "não precisava desejar nada mais belo", não precisava dar mais detalhes em seu relato.

Enfim, a felicidade do menino era uma vivência real e presente, encontrada na plenitude de seus sentidos e no fato de sentir-se acalentado pelo ambiente como um todo, mas ao mesmo tempo, na medida em que sua existência era atravessada por um "forte anseio por coisas belas e distantes" - que ele tinha não mais apenas como criança, mas como adolescente ingressando na vida -, era também o pressentimento de que essa felicidade prosseguiria no futuro, talvez se ampliasse, prolongando as belezas sugeridas naquele espaço-tempo. O fato de muitas figuras e sentimentos surgirem de forma confusa, indefinida, poderia indicar que, para o narrador, seu sentido talvez viesse a deslindar-se no futuro. Essa é uma das funções da atmosfera onírica do escrito: como pressentimento, sugestão de algo indefinido em busca de contornos, em sentido muito próximo dos românticos. Passagens como "os sussurros de amor que à noitinha se misturam ao murmúrio da água"(TraKL 2015: 103), "meus devaneios aéreos, tolamente felizes de menino, que o silêncio amorosamente acolhia e resguardava em si, para por vezes trazê-los de volta a mim mais tarde - nas horas solitárias do crepúsculo" (TRAKL 
2015: 104), “o vento morno do anoitecer soprava pela janela trazendo toda sorte de barulhos confusos aos nossos ouvidos, simulando uma vaga imagem de sonho" (TRAKL 2015: 104), "um sentimento estranho e profundo de bem-aventurança me arrebatava"(TRAKL 2015: 104), "um caloroso arrepio cheio de pressentimentos me perpassava" (TRAKL 2015: 104), "sentia o fermentar da terra úmida e fecunda, esse som misterioso da vida eternamente criadora", "nesses momentos eu percebia obscuramente a grandeza e beleza da vida" (TRAKL 2015: 105), "em meio a todas aquelas flores luminosas sobre as quais grandes borboletas amarelas pairavam oniricamente" (TRAKL 2015: 105-6), e outras, dão notícia de tonalidades ou modulações de um mesmo anseio cheio de pressentimentos que constituía o estado existencial do protagonista, e que em mais de um momento no texto mostra sinais de estar associado ao sentimento de comunhão com a vida, de ser acolhido e mesmo agraciado por ela, como se o presságio de bem-aventurança fosse dado por algo externo, que transcende o sujeito. As duas coisas são inseparáveis: a felicidade presente comporta em si o anseio de futuro na forma de expectativa, entusiasmo e esperança.

Com isso chegamos a um ponto crucial: embora o texto dê a conhecer um estado de unidade e completude, paradoxalmente essa completude não é completa, uma vez que, tingida pelo desejo e pelo lapso e distanciamento que ele carrega, mantém-se em suspenso a possibilidade de uma completude que ainda não é ou ainda não se revelou. Isso está inscrito, num primeiro momento, na pura determinação da Sehnsucht como tal, no caráter de abertura do desejo que não cessa de aspirar. Determinação da temporalidade humana: a completude não é completa porque existe o futuro e esse futuro apenas pressentido é desconhecido e incerto. O paradoxo não é lógico, mas real, e se clarifica ao termos em mente que se trata da transição entre a completude da infância e a incerteza da vida adulta: o momento do paradoxo, a adolescência. A tensão entre completude e incompletude pode ser transposta nos termos da tensão entre infância e iniciação na vida adulta.

Contudo, o desejo por si só, em seu caráter de abertura, não abala a vivência de unidade, pois o presságio, a esperança, o entusiasmo, ao salvaguardarem a vivência de unidade projetando-a para o futuro garantem uma permanência virtual no paraíso da infância, o sentimento de que ele se tornaria ainda mais paraíso, pois "coisas belas e distantes" o esperam. O que surge como elemento destoante e capaz de abalar sua felicidade é antes uma determinação bastante clara e definida, o fato de sua prima, 
Moosburger, L. Traumland

Maria, estar gravemente enferma. Se pudemos abstrair, como proposto, a vivência de unidade harmônica daquilo que viria a quebrar essa Stimmung, essas duas coisas são relatadas lado a lado, de tal forma que o elemento da quebra atravessa a harmonia desde o início, ganhando uma dimensão crescente no texto. Entretanto, a abstração não foi arbitrária: as duas coisas estão em nítida oposição, daí que se trate de uma quebra no estado de espírito do narrador, quebra que o texto exprime de maneira insistente, como buscaremos destacar agora.

No quarto parágrafo, após conduzir-nos ao sótão que habitava na casa de seu tio, o narrador nos dá a conhecer que esse tio passava quase toda a tarde com sua filha doente, para no quinto parágrafo fazer a seguinte revelação:

No começo eu sentia uma espécie de angústia opressa em presença da pequena doente, que posteriormente se transformou em uma timidez sagrada e respeitosa diante desse sofrimento mudo, estranhamente comovente. Ao vê-la, invadia-me o sentimento obscuro de que logo ela teria de morrer. E então eu temia olhar para ela (TRAKL 2015: 104).

A moça, na flor da juventude como o protagonista, com quem ele podia se identificar e por quem nutria carinho - até mesmo uma paixão -, era marcadapor algo que se chocava diretamente com sua vivência de plenitude. Não apenas ela "logo teria de morrer", mas seu estado de saúde não lhe permitia aproveitar o pouco tempo que lhe restava - o narrador deixa claro que ela mal tinha energias para se mover, permanecia recolhida dentro de casa -, era um sofrimento real e presente, que lhe fora dado, também por "mãos desconhecidas", porém não "benevolentes". Tal fato põe em dúvida a consistência da felicidade do jovem, que no auge de sua juventude e saúde se lhe afigurava absoluta, abençoada pelo universo, nele despertando sentimentos contraditórios. No início se sentia angustiado e oprimido perante Maria - por compadecer-se de seu sofrimento, mas também por esse sofrimento refutar a absolutez de sua felicidade? -; depois, divide-se entre, de um lado, uma "timidez sagrada e respeitosa" diante de seu "sofrimento mudo, estranhamente comovente", que a caracterizava como sujeito que sente, e, por outro, o medo diante daquilo que a tomava, a doença e a morte. Determinante é a sua sensibilidade em distinguir radicalmente entre Maria e sua doença: a doença é algo que não lhe é próprio, mas lhe sobrevém e invade, algo de que ela padece, negando o que ela era para ser. É essa percepção que suscita no jovem desconcerto e compaixão. A partir da introdução de Maria, o escrito consiste nos relatos de seus momentos de felicidade marcados por esse elemento dissonante, que 
Moosburger, L. Traumland

surge insistentemente e formulado sempre da mesma maneira: die kranke Maria,"a doente Maria”. Já citamos parte dessas passagens, fazendo abstração do elemento dissonante, agora as transcrevemos na íntegra, para analisar esse movimento de quebra. As passagens consistem em três parágrafos completos. Segue o primeiro:

Quando eu vagava pelas florestas durante o dia, sentindo-me tão alegre na solidão e quietude, quando cansado me esticava sobre o musgo e por horas mirava o céu claro e cintilante, em cujas distâncias se podia olhar tão profundamente, e quando então um sentimento estranho e profundo de bem-aventurança me arrebatava, nesse instante subitamente me assaltava o pensamento de Maria doente - então eu me levantava e, tomado por pensamentos inexplicáveis, vagava sem rumo, sentindo na cabeça e coração um peso aterrador que me fazia querer chorar(TRAKL 2015: 104).

Wenn ich tagsüber in den Wäldern herumstreifte, mich in der Einsamkeit und Stille so froh fühlte, wennich mich müde dannins Moos streckte und stundenlang in den lichten, flimmernden Himmel blickte, in den man so weit hineinsehen konnte, wenn ein seltsam tiefes Glücksgefühl mich dann berauschte, da kam mir plötzlich der Gedanke an die kranke Maria - und ich stand auf und irrte, von unerklärlichen Gedanken überwältigt, ziellos umher und fühlte in Kopf und Herz einen dumpfen Druck, daß ich weinen hätte mögen (TRAKL 2015: 100, grifos nossos).

O parágrafo todo exprime uma experiência de passagem do tempo: começa com um quando (wenn) que se prolonga até o fim, marcado por vários outros ‘quando’ (wenn), 'então' (dann) e 'e' (und) que exprimem sua cadência progressiva, no entanto essa cadência é em certa altura surpreendida por um enfático $d a$ ('então', 'aí'), que interrompe a progressão e altera seu rumo, o que é marcado textualmente pelo advérbio plötzlich e pelo travessão que se seguem ao $d a$. Lendo o parágrafo à luz de nossa análise até aqui, podemos interpretar seu crescendo da seguinte maneira: quando o jovem vagava feliz, pleno do sentimento de pertença e de desejos projetados no céu como um futuro pressentido, quando no auge desse prazeroso devaneio ele era arrebatado por um sentimento estranho e profundo de bem-aventurança, prenhe de possibilidades, nesse instante subitamente lhe assaltava o pensamento de Maria doente. A consciência da realidade de Maria é a tal ponto intensa e impactante, oposta ao sonho e incondizente com sua experiência real e palpável de saúde, frescor, juventude, que o atordoa e desconcerta com "pensamentos inexplicáveis", e o desorienta, fazendo-o "vagar sem rumo"; chocando-se com seu enlevo no sonho, de imediato faz com que este decresça sob um peso aterrador (einen dumpfen Druck) sentido fisicamente, na cabeça e coração, que o faz querer chorar. Ele é tomado de assalto e, passivo, não pode evitar essa reação. O afeto que se desdobra nesse parágrafo começa com a leveza de uma Sehnsucht esperançosa que ascende, progredindo como uma melodia, para subitamente sofrer uma 
Moosburger, L. Traumland

queda, sob o peso aterrador da Schwermut, ânimo pesado. Musicalmente o anseio esperançoso e pleno torna-se uma melancolia na qual se quebra toda a carga afetiva que vinha se desenrolando, como uma decepção. A ênfase dispensada ao $d a$ - advérbio que é tanto temporal quanto espacial, além de explicativo ('então', 'quando', 'aí', 'aqui') -, ao qual se acresce o plötzlich e o travessão, é um detalhe significativo, pois separa um antes e um depois, marca, tensiona e condensa esse instante em que ele se dá conta de "Maria doente". E na medida em que a subjetividade do narrador está totalmente imersa em sua progressão afetiva, nessa vivência musical de harmonia, podemos dizer que esse $d a$ é o instante e o lugar em sua alma em que ele experimenta a saída do sonho, e se parte. Inflado em um tempo indefinidamente longo, em um espaço cósmico que se amplia no infinito, e que o acolhem, sua vivência tem a intensidade de um absoluto, não pode ser relativizada. $\mathrm{O}$ que ali acontece tem um valor igualmente absoluto, ao mesmo tempo que contradiz justamente a absolutez da experiência de felicidade.

A força dramática do parágrafo reside no fato de ele ser contínuo, começar e terminar como um todo, num só impulso: o primeiro 'quando' (wenn) vai-se desenrolando em outros 'quando' (wenn), 'então' (dann) e 'e' (und), de modo que, muito embora em dado momento essa cadência seja interrompida pelo $d a$, ela também se acumula nele, condensando tudo que se desenrolara em cada um desses instantes. Com isso, o parágrafo inteiro faz soar uma progressão cujo desenlace já está contido no começo, uma progressão harmônica que antecipa sua própria quebra. Um dos efeitos disso é a impressão de que a sequência não poderia ter seguido outro rumo, como uma fatalidade. Ao mesmo tempo, porém, na medida em que se trata de um enlevo, um crescendo de anseio e pressentimento, tem-se também a sensação de que esse enlevo não teria fim senão em seu próprio auge - o auge de seu anseio, ou seja, o encontro com o que é desejado -, como se ele pudesse continuar sonhando indefinidamente. De fato, é descrita uma total entrega ao enlevo do sonho. Mas o da que se segue ao ápice da progressão do sonho ("wenn ein seltsam tiefes Glücksgefühl mich dann berauschte") sinaliza antes a quebra dessa progressão - na verdade, o da que quebra é simultâneo ao dann do auge, a quebra se sobrepõe ao auge, anula-o. A segunda passagem segue estrutura semelhante:

E quando às vezes ao entardecer eu ia andar pela poeirenta rua principal, que emanava o perfume das tílias em flor, e via casais sussurrando à sombra das árvores; quando via duas pessoas estreitamente aconchegadas uma à outra e embaladas pelo suave rumorejo da fonte lentamente fundirem-se ao luar como se fossem um só ser, e então um caloroso arrepio cheio de pressentimentos me perpassava, nesse momento me vinha à 
Moosburger, L. Traumland

consciência Maria doente. Uma saudade silenciosa de algo indefinido se abatia sobre mim, e de repente eu me via de braços dados com ela, descendo a rua prazerosamente à sombra das tílias perfumadas. E nos grandes olhos escuros de Maria despertava um brilho estranho, e a lua fazia seu rostinho fino parecer ainda mais pálido e translúcido. Então eu voltava a refugiar-me em meu sótão, reclinava-me à janela, contemplava o profundo céu escuro, no qual as estrelas pareciam se extinguir, e por horas me entregava a turvos sonhos entorpecentes, até que o sono me dominasse (TRAKL 2015: 104-5).

Und wenn ich am Abend manchmal durch die staubige Hauptstraße ging, die erfüllt war vom Dufte der blühenden Linden, und im Schatten der Bäume flüsternde Paare stehen sah; wenn ich sah, wie beim leise plätschernden Brunnen im Mondenschein zwei Menschen enge aneinander geschmiegt langsam dahinwandelten, als wären sie ein Wesen, und mich da ein ahnungsvoller heißer Schauer überlief, da kam die kranke Maria mir in den Sinn; dann überfiel mich eine leise Sehnsucht nach irgend etwas Unerklärlichem, und plötzlich sah ich mich mit ihr Arm in Arm die Straße hinab im Schatten der duftenden Linden lustwandeln. Und in Marias großen, dunklen Augen leuchtete ein seltsamer Schimmer, und der Mond ließ ihr schmales Gesichtchen noch blasser und durchsichtiger erscheinen. Dann flüchtete ich mich in meine Dachstube hinauf, lehnte mich ans Fenster, sah in den tiefdunklen Himmel hinauf, in dem die Sterne zu erlöschen schienen und hing stundenlang wirren, sinnverwirrenden Träumen nach, bis der Schlaf mich übermannte (TRAKL 2015: 100-1, grifos nossos).

Vemos a mesma progressão de um 'quando' que se prolonga, pontuado aqui e ali por outros 'quando' - reveladores de imagens de plenitude exterior que suscitam no jovem o pressentimento de uma plenitude própria -, até um instante inflexivo, um $d a$ em que sua consciência é assaltada por "Maria doente": " $d a$ kam die kranke Maria mir in den Sinn". Entretanto, aqui, em vez de a quebra mudar o rumo de sua caminhada, promove uma refração mais sutil: ao lembrar-se de Maria, é tomado por uma "uma saudade silenciosa de algo indefinido", e ela é incorporada ao seu devaneio - "de repente eu me via de braços dados com ela, descendo a rua prazerosamente à sombra das tílias perfumadas." Em lugar de ser arrancado do sonho e oprimido por uma realidade aterradora, o sujeito se permite - inadvertidamente (visto que, de novo, "de repente", plötzlich) - continuar sonhando. A cena surge vividamente em sua fantasia, ele descreve com detalhe visual que "nos grandes olhos escuros de Maria despertava um brilho estranho, e a lua fazia seu rostinho fino parecer ainda mais pálido e translúcido". Há nessa cena um misto de desejo amoroso com fraterna ternura: a imagem do casal tornando-se um só ser ao luar antecipa o tom romântico-amoroso da cena de braços dados com Maria, a sombra das tílias perfumadas evoca sensualidade, mas "os grandes olhos escuros de Maria" e "seu rostinho fino" parecem suscitar sobretudo um sentimento de ternura, até mesmo um desejo por proteger esse ser tão frágil. A imagem do casal ao luar como presságio, o rumorejo da fonte, a rua durante a noite, o brilho 
estranho nos olhos de Maria, a translucidez de seu rosto à luz da lua, conferem à cena uma aura mística.

A atmosfera de sonho e pressentimento, porém, atinge nessa imaginação do protagonista um ápice que termina como percepção do sonho enquanto sonho, após o que "eu voltava a refugiar-me em meu sótão, reclinava-me à janela, contemplava o profundo céu escuro, no qual as estrelas pareciam se extinguir, e por horas me entregava a turvos sonhos entorpecentes, até que o sono me dominasse." Diante da cena completa, podemos extrair um novo sentido dessa entrega ao sono, que não tem mais apenas um tom positivo de fusão com o universo, na infinitude da noite e do sono, mas o tom negativo de uma fusão que na verdade substitui uma plenitude impossível de ser vivenciada. O "arrepio cheio de pressentimentos" que perpassa o menino em seu passeio noturno, após a visão do casal ao luar, tem uma tonalidade positiva, boa, só que imediatamente lhe vem à consciência "Maria doente". A Sehnsucht, que naquele instante era uma plenitude de pressentimento, torna-se então uma falta: a saudade de algo indefinido, que a imaginação logo define, dando-lhe contornos, ainda que de forma vaga, obscura, estranha - no brilho estranho dos olhos de Maria, em sua palidez -, assim o realizando oniricamente. Maria, no entanto, é impossível. Não apenas para o protagonista, mas impossível em si mesma: a lua revela sua fragilidade, sua doença, que é enfim sua pertença à noite (à morte), não à vida, não à saúde. A lua iluminando a fragilidade de Maria como que misteriosamente a arrebata dele. E é nesse momento que ele retorna ao seu quarto, de encontro ao que também podemos entender como uma espécie de morte: "Então eu voltava a refugiar-me em meu sótão, reclinava-me à janela, contemplava o profundo céu escuro, no qual as estrelas pareciam se extinguir, e por horas me entregava a turvos sonhos entorpecentes, até que o sono me dominasse" (grifo nosso). Nesse momento, ao fundir-se com o todo através da queda no sono, o protagonista carrega consigo um saber - a existência impossível de Maria - incompatível com a felicidade infantil e inocente que, no entanto, o constitui. Tal contradição, não podendo ser assimilada, dá lugar a "turvos sonhos entorpecentes".

Após esse relato, o protagonista conta num curto parágrafo que "no entanto - no entanto não cheguei a trocar dez palavras com a doente Maria. Ela não falava nunca. Apenas sentei-me ao seu lado por horas, e olhei em seu rosto doente, sofredor, sentindo toda vez que ela tinha de morrer" (TRAKL 2015: 105), salientando, pela repetição "Und doch - und doch...", a barreira imposta pela realidade. E prossegue: 
Moosburger, L. Traumland

No jardim, eu me deitava na grama e aspirava o perfume de mil flores; meus olhos se embriagavam com as cores vibrantes das inflorescências inundadas pela luz do sol, e eu ouvia a quietude do ar, só ocasionalmente interrompida pelo chamado de um pássaro. Sentia o fermentar da terra úmida e fecunda, esse som misterioso da vida eternamente criadora. Nesses momentos eu percebia a obscura grandeza e beleza da vida. Nesses momentos eu também sentia como se a vida me pertencesse. Mas então meu olhar pousava sobre a janela da sacada. E lá eu via a doente Maria sentada, quieta e imóvel, de olhos fechados. E toda a minha consciência era novamente absorvida pelo sofrimento desse único ser, e lá permanecia, tornando-se uma nostalgia dolorosa, apenas timidamente admitida, que se me afigurava incompreensível e desconcertante. Quieto e envergonhado, eu deixava o jardim, como se não tivesse nenhum direito de permanecer nesse santuário (TRAKL 2015: 105).

Tal como nos parágrafos anteriores, o narrador relata uma vivência de profunda intimidade com a vida, e no momento em que está no auge dessa vivência, sentindomeditando a "beleza e grandeza da vida", tomado pelo sentimento de conspiração do universo com seu íntimo, de que a vida lhe pertencia, é subitamente interrompido, agora não pela lembrança ou pensamento em Maria, mas por sua presença:

[...] Damals fühlte ich dunkel die Größe und Schönheit des Lebens. Damals auch war mir, als gehörte das Leben mir. Da aber fiel mein Blick auf das Erkerfenster des Hauses. Dort sah ich die kranke Maria sitzen - still und unbeweglich, mit geschlossenen Augen (TRAKL 2015: 101, grifo nosso).

Também aqui ocorre um crescendo de felicidade e então uma quebra. Também aqui o advérbio de tempo que sinaliza o auge (damals) antecipa aquele que indica a quebra $(d a)$. O jovem sente a plenitude de vida, a terra eternamente criadora; mas a existência de um único ser não abençoado por tal plenitude o perturba, salta à sua vista de forma inelutável: "Und all' mein Sinnen wurde wieder angezogen von dem Leiden dieses einen Wesens" - os sentidos e a consciência com que ele plenamente fruía a vida são tomados pela impossibilidade de Maria participar dessa plenitude, e Maria se torna um fulcro que atrai seu olhar como um ímã. Tomado por essa realidade, seus sentidos e consciência se demoram: "lá permaneciam, tornando-se uma nostalgia dolorosa, apenas timidamente admitida (einer schmerzlichen, nur scheu eingestandenen Sehnsucht), que se me afigurava incompreensível e desconcertante". Incompreensível e desconcertante é a discrepância entre a plenitude e a falta, entre sua saúde e a doença de Maria, entre seus sentidos abertos para o mundo vivo, e os sentidos embotados para o prazer, tomados pelo sofrimento, de Maria, sentada imóvel de olhos fechados, do lado de dentro da casa. Incompreensível e desconcertante é também sua saudade timidamente admitida: tímida por ele ter sido abençoado com a saúde e ela não, tímida porque voltada para um ser diante do qual sentia compaixão e respeito. Essa timidez vincula-se a um sentido ético- 
Moosburger, L. Traumland

religioso profundo: "Quieto e envergonhado, eu deixava o jardim, como se não tivesse nenhum direito de permanecer nesse santuário”.

Podemos fazer aqui uma reflexão sobre como a passividade sensitiva do jovem termina ela mesma por mobilizá-lo para fora do sonho. Na plena abertura de seus sentidos, ele se deixa sentir, tomar e enlevar, é como que carregado, pelos diversos estímulos externos, para o interior de sua subjetividade, que projeta e inadvertidamente impõe sua dimensão no mundo externo. Entretanto, a mesma sensibilidade pela qual ele desfrutava a beleza do jardim lhe faculta tomar consciência do sofrimento de um outro, arrancando-o de seu deleite onírico e fazendo-o ver uma realidade além daquela que lhe é autoevidente. Digna de nota é a expressão all mein Sinnen: significando a uma vez 'sentidos' e 'consciência', ela destaca um sentido de totalidade da consciência que não pode ser separada dos sentidos e do sentimento. Em uma profunda intuição, o protagonista sai de seu seguro sentimento do infinito e se confronta com a finitude radical a partir da realidade de um outro, uma realidade que não pode ser justificada, a doença e a morte de um ser inocente. Sua conclusão de que "não tinha direito a permanecer nesse santuário" reflete o valor absoluto dessa experiência que, como mencionamos anteriormente, contradiz a absolutez de sua felicidade.

Até aí, sua conclusão parece conter exclusivamente um tom negativo de impossibilidade ou obstrução. Entretanto, a saída do sonho supera a pura passividade não só no sentido de uma tomada de consciência, mas também no de uma passagem à ação:

Sempre que eu passava ali pela cerca, perdido em pensamentos colhia uma daquelas grandes rosas de um vermelho luminoso, pejadas de perfume. E quando estava para passar silenciosamente pela janela, eu via a sombra suave e oscilante da figura de Maria no caminho de cascalho. E minha sombra tocava a sua como em um abraço. Naquele instante, como que tomado por um pensamento impetuoso, eu entrava pela janela e depositava sobre o colo de Maria a rosa que acabara de colher. E então me esgueirava silenciosamente para fora, com medo de ser surpreendido (TRAKL 2015: 105).

A primeira metade do parágrafo acerba o sentimento trágico do encontro impossível, do desejo que não se cumpre, tensionado nessa imagem de encontro ilusório das "sombras que se tocam como em um abraço". E é nesse acerbamento que o menino é levado à ação: o gesto singelo de apenas ofertar a rosa que acabara de colher (novamente o desenrolar da cena é antecipado desde o início, pois ao colher a rosa perdido em pensamentos ele parece já ser levado a isso pela intenção de ofertá-la). Entretanto, esse singelo gesto carrega uma intensidade e sentido metaforizados na descrição da rosa: "de um vermelho luminoso, pejada de perfume". Ofertar a expressiva, viva rosa não é 
Moosburger, L. Traumland

apenas expressar seu desejo pela moça. Ele oferta a rosa como quem oferta a vida. Tenta levar até ela um pedaço do paraíso. A rosa condensa em si tudo que ele podia vivenciar, e é como se através dela ele pudesse de algum modo dar vida à jovem e, assim comunicando-lhe seu desejo por ela $e$ seu desejo de que ela pudesse ter o que ele tem, conseguisse transcender a barreira imposta pela realidade. O "pensamento impetuoso" que o leva a subir a janela em uma demonstração de romantismo não é só o desejo por Maria, mas o desejo de que Maria pudesse ser, o desejo de salvar um ser morrendo. A dimensão humana, espiritual e ética desse pequeno gesto se destaca ao compreender-se a dimensão de um ser a quem a própria vida é negada. O protagonista era ciente disso:

Quantas vezes esse pequeno acontecimento que me parecia tão significativo não se repetiu! Não sei. Para mim, é como se eu tivesse depositado mil rosas sobre o colo da doente Maria, como se nossas sombras tivessem se abraçado incontáveis vezes. Maria nunca fez menção a esse episódio; mas eu sentia, pelo brilho de seus grandes olhos iluminados, que ela se alegrava com isso (TRAKL 2015: 105).

Nesse breve instante de cumplicidade, realiza-se a versão possível do encontro sob as tílias apenas imaginado pelo narrador. Tudo que pôde realizar foi esta pequena alegria.

Meu velho tio consentia com esse nosso silêncio. Mas certa vez, quando me sentava com ele no jardim, em meio a todas aquelas flores luminosas sobre as quais grandes borboletas amarelas pairavam oniricamente, ele me disse com uma voz branda e pensativa: "Sua alma vai atrás do sofrimento, meu jovem." E ao dizê-lo pôs sua mão em minha cabeça e parecia querer dizer mais alguma coisa. Mas calou-se. Talvez ele também não soubesse o que havia despertado em mim e com que poder isso viria a me habitar desde então(TRAKL 2015: 105-6).

Anteriormente interpretamos o consentimento do tio como uma versão humana do consentimento, sentido pelo protagonista, de uma esfera mais ampla, cósmica. Nesta sequência, o tio traz uma espécie de presságio no qual já foi incluída a quebra do sonho do protagonista, ou seja, a quebra do consentimento dessa esfera mais ampla. O presságio é uma corroboração de sua conclusão no jardim: em vez de fruir o que lhe é dado, ele vai atrás do sofrimento; um sofrimento, portanto, que a rigor não precisaria ser seu, mas que ele não é capaz de evitar sentir e mesmo procurar. Mas essa frase merece mais atenção. Por um lado, podemos dizer que ele não foi atrás do sofrimento ao contrário, perseguia o prazer harmônico da natureza, desfrutava de seus sentidos, etc. -, e sim o sofrimento se mostrou para ele. Entretanto, ele se rende a essa revelação, decide não ignorá-la, e nesse sentido vai atrás do sofrimento: concluindo que "não tinha nenhum direito de permanecer nesse santuário”. A fala do tio, a propósito, apesar de sua apreensão, parece funcionar antes como um fomento do que como um alerta 
desencorajador: "Talvez ele também não soubesse o que havia despertado em mim e com que poder isso viria a me habitar desde então." É como se o protagonista se apropriasse da fala do tio para corroborar a sua própria conclusão, como um presságio que deve ser cumprido. Nesse sentido, é também como se ele ainda adivinhasse um propósito dado por uma esfera exterior, que o transcende; um propósito que se inverteu. A figura do tio também pode ser pensada como uma projeção do protagonista, um alter ego que na verdade é uma aparição dele mesmo mais velho: a presença do narrador adulto no passado rememorado, o que se coaduna com o movimento rememorativo do texto, de projeção e retorno.

Chegando ao fim de seu relato, o narrador descreve o já esperado momento:

Um dia, quando novamente fui à janela à qual Maria estava sentada como de costume, vi que seu rosto estava pálido e petrificado na morte. Raios de sol deslizavam por sua figura brilhante e delicada; seus cabelos dourados esvoaçando soltos ao vento, para mim era como se nenhuma doença a tivesse levado, como se tivesse morrido sem causa visível - um enigma. A última rosa, depositei em sua mão, e ela a levou para o túmulo (TRAKL2015: 106).

À diferença de poemas futuros de Trakl, aqui o narrador parece ver apenas beleza no rosto da morte - por assim dizer o lado mais romântico do romantismo, em contraste à percepção do feio, do horrível e da deterioração que foi elaborada pelo romantismo negro e ressurge no expressionismo, e que Trakl elaborou em sua lírica. A visão de Maria morta suscita nitidamente um sentimento do numinoso no protagonista. Entretanto, ele não atribui aqui, de maneira decidida, um sentido transcendente à morte. Se a doença orgânica parece ser desautorizada como causa da morte e em seu lugar entra um mistério, um enigma (ein Rätsel), em nenhum momento o narrador chega a interpretar um sentido à morte, uma transcendência que a justifique, antes parece perplexo diante do inexplicável. Pode-se supor que, senão toda, grande parte de sua perplexidade diz respeito à falta de sentido de toda a situação de doença e impossibilidade de vida justamente no momento em que os anseios juvenis estão em expansão. O “enigma”, ao qual o narrador aliás não arrisca interpretação alguma, parece antes indicar que todo seu desejo por descobrir um sentido oculto se abstém, se cala.

A morte de Maria marca o egresso da terra dos sonhos, que é o fim da narrativa:

Logo após a morte de Maria eu parti para a cidade grande. Mas a lembrança daqueles dias quietos cheios de luz solar permaneceu viva em mim, talvez mais viva do que o tumultuoso presente. Nunca mais verei a pequena cidade ao fundo do vale - sim, tenho medo de voltar a procurá-la. Creio que não poderia fazê-lo, ainda que tantas vezes me sobrevenha uma forte saudade daquelas coisas eternamente jovens do passado. Pois sei que procuraria apenas em vão por aquilo que se foi sem deixar rastros; não encontraria 
mais lá o que só ainda em minha memória vive - como o presente - e isso provavelmente me seria apenas uma tortura inútil(TRAKL 2015: 106).

O texto termina com o narrador reafirmando as saudades da infância, retomando a memória perdida no presente. Como observa BLASS (1968: 32), o texto se completa no movimento recordativo. O que se lamenta, porém, é a perda não apenas da infância, mas daquele lugar mesmo, "aquelas coisas eternamente jovens do passado", que contrastam com a ruidosa cidade grande, símbolo da perda do sonho juvenil de unidade com a vida, a natureza e o mundo. O passado, que fora vivido como intemporal, mostra-se agora exclusivamente como passado, e sua própria intemporalidade se desfaz como ilusão. $\mathrm{O}$ narrador não está a lamentar apenas a perda do passado, mas a perda de sua consistência, o caráter onírico da experiência de unidade lá vivenciada. Ao sentimento de perda acresce o sentimento de ser vivido e não viver, de ser passivo e não poder agarrar as coisas (tal como não podia impedir a morte de Maria), sobretudo de não poder realizar o antigo e juvenil "desejo por coisas belas e distantes", devido à dissonância entre eles e a realidade. Como interpreta BLASS (1968: 33), a terra dos sonhos foi apenas um episódio.

\section{Considerações finais}

Um dos principais traços que caracteriza a infância como paraíso é a possibilidade de viver imerso no sonho, de viver a própria subjetividade como um absoluto. O narrador resume isso referindo-se ao passado "como uma vida fantástica e maravilhosamente vivida", que "podia desfrutar sem hesitação como um presente recebido de mãos benevolentes e desconhecidas": a vida era uma dádiva a ser usufruída, um sonho a ser sonhado, o que lhe parecia garantido pelo sentimento de cumplicidade com sua ambiência, ampliado a uma dimensão cósmica absoluta. Nessa entrega e recolhimento no sonho podemos entrever uma busca romântica (ao modo de Novalis) por continuar sonhando, como indicam as cenas em que ele voltava a seu quarto para "sonhar por mais uma hora noite adentro". Tal absolutez é porém perturbada quando ele permite que Maria entre na esfera de seu sonho e desejo. É então transtornado pela impossibilidade de ela participar dessa esfera, e atraído para a zona obscura do sofrimento irremediável, na qual os desejos têm de morrer. Ele enfatiza esse movimento diversas vezes marcando 


\section{Moosburger, L. Traumland}

com o advérbio da o instante em que é puxado para fora do sonho, ao pensar, lembrar ou visualizar Maria. Como um compasso musical, esse da marca ao longo do texto o lugar-tempo de uma tensão transformadora, em que a harmonia absoluta realmente vivenciada, tanto quanto a pressentida e desejada, são perdidas. Nesse sentido, o termo ‘episódio' refere-se ao episódio inesperado e incontornável - a doença em Maria - que vem perturbar sua fé na felicidade e identifica sua passagem da infância à idade adulta com a perda do sentimento de harmonia cósmica. As "primeiras impressões de uma grande experiência" não afetaram apenas a "felicidade indescritível" realmente vivenciada, mas, junto com ela, o "forte desejo por coisas belas e distantes" que a preenchia. Se a Sehnsucht "perturba o homem em sua juventude como um anseio por algo desconhecido" e no futuro "se volta para trás com uma dor profunda pelos ideais perdidos",Traumland é o lugar-tempo de uma experiência de felicidade que se torna impossível, é ao mesmo tempo o lugar dos sonhos e de sua dissipação. O texto é assim construído sobre uma ambivalência na função do sonho: há o sonho no sentido de consonância com o universo, que foi realmente vivenciado, mas simultaneamente há a consistência onírica dessa vivência que se tornou apenas a lembrança de um passado pleno, aparentemente interminável, tendo agora um aspecto irreal e fantástico (wundersam) de sonho. Com isso, a consistência do presente também se dissipa no sentido de uma irrealidade, esvazia-se, pois perdeu os ideais da juventude. Todo o texto é marcado pela experiência já efetuada de perda do ideal: a melancolia se faz como perda de um tempo no qual o protagonista sonhava e projetava uma plenitude que, através da tragédia de Maria, tornou-se impossível para ele. Que a palavra Sehnsucht tenha, depois disso, vindo a se calar em sua poesia, não significa a perda do desejo romântico, mas o sentimento de não ter direito ao sonho romântico compartilhado com o Universo: um recolhimento melancólico, uma necessidade de emudecer o anseio, como única forma de corresponder ao silêncio de Deus que constantemente exprime em sua poesia a misteriosa mudez e abstenção de Deus perante o sofrimento da criatura.

Blass não identifica na morte de Maria nenhuma reviravolta, e diz que esse evento, ao contrário do que se poderia esperar, permanece sem sequência (1968: 11). Entretanto, a morte de Maria já está acontecendo na pena e fatalidade da doença, que ocupa o foco da narrativa e mobiliza uma profunda mudança no sentimento e visão de mundo do protagonista. Toda a peça não é senão um evento transformador. 
Esse evento tem claras semelhanças com aquele que dá ensejo aos Hinos à Noitede Novalis: a morte da jovem amada vitimada por uma doença. O sentimento de sintonia com a noite e o sonho, em contraste (no caso de Novalis) à agitação diurna do mundo(Novalis 1998: 22-3;28-9) e (node Trakl) ao tumultuoso presente da cidade grande, indica um mesmo desejo de infinitude e busca por transcendência. Mas as experiências se desdobram em direções opostas. Novalis encontra sentido na morte da amada, a esperança de uma transcendência que será evocada pelo canto poético e sentida numa experiência mística. Em Traumland, a sintonia cósmica, sobretudo através da noite e do sonho, é lembrada com triste nostalgia, como já perdida, e narrada como algo que está em vias de se desfazer e se desfaz. O 'enigma' da morte de Maria não remete aos 'infindáveis segredos' que o eu lírico dos Hinos adivinha na noite (NovALIS 1998: 22-3). Ao aperceber-se do caráter onírico de suas vivências, o narrador de Traumland tampouco reage conforme o mote novalisiano de que o sonho resguarda uma realidade mais alta, mas sente-se decepcionado por perceber que era apenas um sonho.

As duas nuances de sonho que frisamos em nossa análise- sonho no sentido de enlevo/desejo e sonho como consistência da realidade, condição existencial permanente - ajudam-nos a dimensionar essa relação com o romantismo. No romantismo, há uma sintonia entre esses dois sentidos, pois o sonho é via de acesso a um plano mais verdadeiro da existência, podendo por isso tornar-se um imperativo e realizar a liberdade espiritual. O protagonista de Traumland experimenta uma quebra entre esses dois sentidos de sonho: seu sonho bom, o idílio da infância, não pode prosseguir, pois Maria não pode vivê-lo, e essa impossibilidade é que se torna para ele a realidade mais forte. O mal irremediável da jovem, porém, ocasiona a perda de toda a dimensão do idílio: o texto termina no sentimento vazio da cidade grande que, em oposição à vida singela das pessoas na cidadezinha, é uma imagem mais apropriada para a realidade do séc. XX que Trakl conheceu - a cidade desumanizada, o mundo em guerra, a perda da dimensão sagrada da natureza. Trakl se tornou um estrangeiro- na expressão de Heidegger, perdeu seu $d a$, seu "aí" -,um desterrado da terra dos sonhos, um romântico que não pode ser romântico. Mas se em Traumland vemos um eu perdendo seu romantismo, não se trata de uma recusa meramente estética, e muito menos de um desejo seu, e sim de uma recusa conceptiva, de visão de mundo, no sentido preciso de que, diante de um mundo em ruína, o eu, que não pode abster-se de olhar para os aspectos brutais e sombrios da existência, passa a incluí-los no cerne de sua expressão, refletindo a condição de um protagonista que sofre o sonho involuntariamente, um 
sonho-pesadelo, como terrivelmente cantado no poema Confiteor (TRAKL 1969: 246; a presente tradução é nossa):

As imagens multicores pintadas pela vida Só as vejo enegrecendo em cada entardecer, Como sombras crespamente deformadas - turvas,

[frias -

De que a morte se apropria mal acabam de nascer.

E porque a máscara caiu de cada coisa, Só vejo medo, desespero, praga e maldições, A tragédia humana sem qualquer figura heroica, Um pérfido teatro sobre corpos e caixões.

Repugna-me essa onírica visão cruel. Mas um forte mandamento obriga O comediante a recitar o seu papel, Coagido e cheio de aflição - monotonia!
Die bunten Bilder, die das Leben malt

Seh' ich umdüstert nur von Dämmerungen,

Wie kraus verzerrte Schatten, trüb und kalt,

Die kaum geboren schon der Tod bezwungen.

Und da von jedem Ding die Maske fiel,

Seh' ich nur Angst, Verzweiflung, Schmach und

[Seuchen,

Der Menschheit heldenloses Trauerspiel,

Ein schlechtes Stück, gespielt auf Gräbern, Leichen.

Mich ekelt dieses wüste Traumgesicht.

Doch will ein Machtgebot, daß ich verweile,

Ein Komödiant, der seine Rolle spricht,

Gezwungen, voll Verzweiflung - Langeweile!

Como se tudo, tal como a jovem Maria, houvesse sido apropriado pela morte antes mesmo de poder viver. Não a morte-transcendência, mas a morte corrosiva, sem transcendência, a morte que é mera destruição do tecido da vida. Nesse poema exprimem-se os dois conhecidos motes do poeta - "não tenho o direito de me furtar ao inferno", "teu poema é uma expiação imperfeita" - sob a forma clara da confissão de uma culpa - Confiteor, latim, significa “confesso". Por que culpa? O eu lírico assume a culpa pelo horror do mundo inteiro - não apenas a doença da jovem, "o sofrimento desse único ser" que o impedia de sentir justa sua fruição do jardim, mas o da guerra, da desumanização do mundo, da dessacralização da natureza -, talvez como o último refúgio para não perder a fé no Deus ausente, aquele que por abster-se permite a penúria e o horror; para não culpar o próprio Deus, para não se tornar ateu. Ele assume como um forte mandamento o papel de revelar o mal, papel que ele não escolheu, mas lhe foi dado, talvez por esse mesmo Deus. "Maria", significativamente o nome da mãe de Deus. A morte de Maria é um evento transformador na poesia de Trakl como um todo: insígnia do homem órfão de Deus que é o homem nascido em seu tempo, e que ele encarnou; insígnia, também, da morte do feminino em um sentido profundo: elemento acolhedor, capaz de salvar o masculino da guerra e da autodestruição. 


\section{Referências bibliográficas}

BEGUIN, Albert. El alma romântica y el sueño.México: Fondo de Cultura Economica, 1954.

BLASS, Regine. Die Dichtung Georg Trakls. Von der Trivialsprache zum Kunstwerk. Berlin: Erich Schmidt, 1968.

Chevalier, Jean; GHeERbrant, Alain. Dicionário de Símbolos. Rio de Janeiro: José Olympio, 1989.

KASACK, Hermann. Deutsche Literatur im Zeichen des Expressionismus. Merkur,v.15, n.158, p. 353363, abr. 1968.

KIRCHNER,Friedrich;MICHÄELIS, Carl. Wörterbuch der Philosophischen Grundbegriffe. Leipzig: Verlag der Dürr'schen Buchhandlung, 1907.

KLEEFELD, Gunther. Das Gedicht als Sühne: Georg Trakls Dichtung und Krankheit. Eine Psychoanalytische Studie. Tübingen: Niemeyer, 1985.

LindenBERgER, Herbert.The Early Poems of Georg Trakl.The Germanic Review: Literature, Culture, Theory, v. 32, n. 1, p. 45-61, 1957.

LÖHR, Katja. Sehnsucht als poetologisches Prinzip bei Joseph von Eichendorff. Würzburg: Königshausen \& Neumann, 2003.

MAlPAS, Jeff. "Philosophy's nostalgia”. In: KenAAn, Hagi; FEBERT, Ilit.(Ed.). Philosophy's Moods. The affective grounds of thinking.New York: Springer, 2011.p. 87-101.

Novalis. Hinos à Noite. Lisboa: Assírio \& Alvim, 1998.

Rolleston, James. The Expressionist Moment: Heym, Trakl and the Problem of the Modern. Studies in 20th Century Literature, v. 1, n. 1, p. 65-90, jan. 1976. Disponível em: <http://dx.doi.org/10.4148/2334-4415.1033>. Acesso em: 10 mar. 2017.

SPITZER, Leo. Explication de Texte Applied to Walt Whitman's Poem "Out of the Cradle Endlessly Rocking”. In: ELH, v. 16, n. 3, p. 229-249, set. 1949. Baltimore: The Johns Hopkins University Press, 1985.Disponível em: <http://www.jstor.org/stable/2871732〉. Acesso em: 10 mar. 2017.

TRAKL, Georg. Do cálice dourado/ Aus goldenem Kelch. (n.t.) Revista literária em tradução, v. 1, n. 12, jun. p. 152-172, 2016.Disponível em: <http://www.notadotradutor.com/revista.html>. Acesso em: 03 abr. 2017.

TRAKL, Georg. Dichtungen und Briefe. Historisch-Kritische Ausgabe. Editada por Walther Killy e Hans Szklenar. Salzburg: Otto Müller Verlag, 1969.

TRAKL, Georg. Terra dos Sonhos - um episódio/ Traumland - eine Episode. (n.t.) Revista literária em tradução n. 11, v. 2, p. 98-106, dez. 2015. Disponível em: <http://www.notadotradutor.com/revista11.html>. Acesso em: 03 abr. 2017. 